\title{
PROTECTION SYMBOLS ON THE TOP OF THE MIDDLE KINGDOM STELAE (IN CAIRO MUSEUM)
}

\author{
El-Toukhy, M. \\ Assist. Lecturer, Ancient Egyptian dept., Faculty of Archaeology and Tourism Guidance, Miser Univ. for \\ Science and Technology, $6^{\text {th }}$ October, Egypt. \\ E-mail: mohsen-toukhy@hotmail.com
}

\begin{abstract}
In ancient Egypt, Stela was decorated with a lunette, which is composed of special elements. These lunettes were both symbols of protection and defense. In Middle Kingdom stelae, one may find many protecting symbols; such as Wadjet-eyes, Jackel, and Winged sun-disk, all of these symbols are represented upon top of stelae in different forms. The research aims to throw light on the different forms of top of stelae decorating symbols of Middle Kingdom especially those located in Cairo Museum.
\end{abstract}

Keywords: Stelae, Symbols, Wadjet-eyes, Top of Stela, Decoration, Middle Kingdom

\section{Introduction}

Ancient Egyptian art is more than five thousand years old. It emerged and took shape in ancient Egypt, the civilization of the Nile Valley. Expressed in paintings and sculptures, it was highly symbolic and fascinating - this art form revolves round the past and was intended to keep history alive. This paper is concerned with the Middle Kingdom stelae actually stored of the Cairo Museum. When I started to collect different stelae for comparative purposes, I soon realized that they should be dated to the same period presenting the similar features and displaying the different symbols that are used on the top of stela decoration during the Middle Kingdom, it examines the emergence of some of

\section{Stelae}

Egyptian stelae have set within the tomb, whether in chapels or carved the symbols at the top of the stelae in the Middle Kingdom. In spite of the importance of the purpose of their decorative symbols but it does not eliminate the religious content of its legendary. Due to the highly religious nature of ancient Egyptian civilization, many of the great works of ancient Egypt depict gods, goddesses, and Pharaohs, who were also considered divine. Symbolism also played an important role in establishing a sense of order. Symbolism, ranging from the Pharaoh's regalia (symbolizing his power to maintain order) to the individual symbols of Egyptian gods and goddesses, which was omnipresent in Egyptian art.

on both sides of the entrance that leads to the chapel [1], or based on the wall of 
the tomb [2] [3], also were individually in front of the tomb [4]. They guide the owner's soul to the burial place, and are considered a witness of the ownership of the owner of stela of the tomb [5]. In other words, they ensure that this tomb belongs to him [1]. Müller divided the ancient Egyptian stelae in terms of shapes and places into three groups [2]: * The form of the stelae of $1^{\text {st }}$ dynasty kings in Abydos, which were held independently and their late forms were based on a vertical wall. * The developed form from offering niches in the outer wall of the tomb in the $2^{\text {nd }}$ dynasty in which the offerings were represented. From the $5^{\text {th }}$ dynasty demonstrated on both sides with

\subsection{Terms}

In ancient Egypt, stelae are slabs of stone or wood, of many different shapes, usually bearing inscriptions, reliefs or paintings. There

rounded statement, and Cornice from the top, which is already a tradition of Bous buildings. * The indifferent form that don't belong to the previous two forms, and acquires its importance from the scenes and inscriptions, and must distinguish between tomb stelae, that distinguish the tombs known since the $1^{\text {st }}$ Dynasty, which may consider tombstone which don't carry only the deceased name and the depiction of him, but determined as well as the place of offerings, and the monuments related to persons or certain events, especially that with a religious meaning that were common in the Middle Kingdom.

are several ancient Egyptian expressions for the term stela, which reflect its different purposes, as follows:

1- $w d$ : with the meaning of stela/ tombstone and written by different forms: 9 P

2- ${ }^{\circ} b 3$ :with the meaning of Stela/ offering stone/ tombstone and written by different forms: 0 3- ${ }^{C}{ }^{c} w$ : with the meaning of Stela/ memorial Stone and written by different forms:

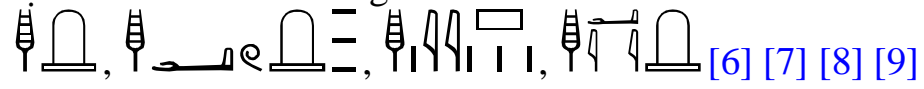

4- $s r h$ : with the meaning of tombstone/ memorial stone and written by the form: $\prod_{\ominus} \square_{[8]}$

5- sps: with the meaning of tombstone and written by:

There are specific determinatives that are used to give the meaning of stela in ancient Egypt; they are listed

- "O" 39:

• "O" 26: Д

• "Q" 6:

— "P" 6: 貝

\subsection{Definition}

The word 'Stela' in defining a stone or wooden slab, generally taller than it is wide erected for funeral or as in Gardiner sign-list [10] as the following: commemorative purposes, most usually decorated with the names and titles of the deceased or living inscribed, carved 
in relief (bas-relief, sunken-relief, high-relief, and so forth), or painted onto the slab. It can also be used as a territorial marker to delineate land

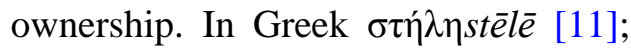
plural: $\sigma \tau \hat{\jmath} \lambda \alpha$ stēlai which means pillar or vertical tablet. There are many models of stelae in ancient Egypt and varied scenery and decoration patterns, these stelae have been developed through several stages - since the Predynastic period and even up to the Greek and Roman Periods - this development includes their forms, scenes and decorations. Moreover, in the Middle Kingdom, the so-called classical stela dominated, since it is shaped as a rectangle stone pallet, which is sometimes styled with rounded-top, most probably symbolizing the firmament. [12]. All kinds of stelae are used in Egypt in different eras, perhaps

\section{Protection Symbols}

Stelae usually have both depictions and inscriptions, executed in raised or sunken relief, or painted onto the surface. The space within the top curve of a stela is called the lunette, and it is composed of special decorative elements. On Middle Kingdom stelae, the decoration of the lunette is clearly differentiated from the rest. Typical elements used in decorating the lunettes were, for example Wedjat-eyes and the winged sun disk, both symbols of protection

\subsection{The winged sun-disk}

The sun-disk is used in the ancient Egyptian Art in many different forms of metaphorical expression of concepts associated with solar faith [12], and the winged sun disk in one of its most common forms [12]. Winged sun-disk seems to be appeared first in Edfu and reflects the union earths, which symbolize the two wings to Upper and Lower Egypt, the same idea appears in decorating the sun disk by couple of uraei [12]. It decorates top of its first appearance was found in the $1^{\text {st }}$ Dynasty, that there was found Merka Stela near many chapels that adorned the eastern façade of one of the Mastabas at Saqqara [5]. Middle Kingdom stelae were distinguished by its size magnitude, and they represented the scenes of its owner, and rarely represented gods on them, except the purpose of protection [5]. Roundedstela style were common used also rectangular and of irregular shape in the Cairo Museum Middle Kingdom stelae. In the selected stelae exist an unusual type of stela with curved base CG 20359. Most of the studied stelae are made of limestone. However, there are some stelae made of sandstone. The use of high and low relief, as well as drawing and coloring instead of engraving are the most common used.

and defense. Symbols for "life" and "regeneration," such as the $\check{n} n$-ring or the nH-sign, as well as depictions of deities (especially Wepwawt and Anubis), have also appeared in the lunettes. In this paper, the symbols which decorated the top of stela in the Middle Kingdom will be analyzed through the symbols, Winged SunDisk, wDAt, Sn, Vessel iab, Water sign $\mathrm{n}$ and the Jackel, as follows:

rounded-stelae, rarely rectangular and of irregular shape. Usually was above a scene a God. Doha mentioned that the winged sun-disk is still deployed above the deity to whom the offering is the dedicatee [13], also seems it is more suitable for the protection of the gods. It first appeared in Third dynasty scenes [12], and in decorating the top of rounded-stelae since Middle Kingdom [14]. Werbrouk pointed out that the two wings are not connected to 
sun-disk, but instead they meet below. So the wings are separated from the dick. [15]. There are only two winged sun disk forms appeared in Middle Kingdom Stelae: 1- The simple form committed with couple of uraei@OS making the form $\mathrm{CG}$ 20678, perhaps the wings protects the scene and the uraei protects the sun-

\subsection{The Deities}

The divine figures on private stelae of the Middle Kingdom are certainly the most characteristic feature in the evolution of these monuments after the First Intermediate Period [16]. Rarely deities were represented on top of stelae within a symbol as in: CG 20089 which was decorated by God

\subsubsection{The Jackel ${ }^{\text {s-q }}$}

The Jackel is the form of God Anubis, Lord of the Mummy Wrapping, one of the very old Gods, and also refers to God Wepwawt, Opener of the way. Most likely jackels were associated with death because they had been observed eating corpses, But Armour cited that Flinders Petrie speculated that the animals assembled in graveyards to feed off the offerings left there to honor the dead. However, Armour suggested another explanation for the cult of Anubis is that rituals in honor of the jackel were an attempt to put a benevolent interpretation on his practice of digging for bones in graveyards, that perhaps Anubis would use these macabre habits for good 3.2.1.1. Combined symbols

Two jackels represented on top of stela separated by the ring $\mathrm{Sn}$ in

\subsection{The Wedjat-eyes}

At the beginning of history the High God of the Egyptians was a falcon which was shown either as perching on a building or emerging from the Primeval Waters. Its right eye was the sun and the left one was the moon [13]. Certainly, whenever the Egyptians pictured the eye of their god disk as Doha cited [13], which appeared in few examples ${ }^{(a)}$. 2- The last form with long uraei example: CG 20601. The winged sundisk represented combined with the wedjat-eyes and two jackels in: CG 20397.

Min standing before a peculiar symbol and facing a jackel with the name of god Wepwawt and his titles, also in CG 20085 which was decorated by God Osiris standing before a peculiar symbol and facing a jackel with the name of god Wepwawt and his titles.

rather than evil [17]. The jackel represented lying or standing on the top of stelae to guarantee the sun-rays that brings light to the afterlife [12]. It was represented upon top of stelae added to it the name of God Anubis or God Wepwawt, and sometimes both of them. The Jackel with the name of Anubis was representing on top of stelae together with the jackel with the name of Wepwawt as in: CG $20093^{\text {(b) }}$. However, there are stelae represented upon it two jackels without names, as in: CG $20177^{\text {(c) }}$. The Wepwawt jackel was represented alone in: CG 20596, and represented as double jackels in CG $20557^{(\mathrm{d})}$.

only one example: CG 20732 as 棺转.

they depicted a falcon's eye, not a human one [18]. This Symbol is derived from the ancient myth according to which the eye of the falcon-god Horus, often depicted on the monuments in the form that was torn into fragments by the wicked god Seth. Later, the Ibis-god Thoth 
miraculously 'filled' or 'completed' $\mathrm{mH}$ the eye, joining together the parts, whereby the eye regained its title to be called $w d 3 t$, 'the sound eye' [10]. It appeared on sarcophagus since Middle Kingdom not only for protecting the owner of the stela [13], but also to 3.3.1. The Eyes alone

It is the most common symbols used in decorating top of stelae also false doors in the ancient Egyptian especially in Middle Kingdom, the eye appeared alone in a couple form, two eyes facing each other It also appeared on non-royal stelae since twelve dynasty [5]. As detailed above,

\subsubsection{The Wedjat-eyes combined with other symbols}

The Wedjat-eyes were represented combined with other symbols: 1The Wedjat-eyes with Sn: Both Wedjat-two eyes may be represented separated by the sign $\mathrm{Sn}$ to make the combination represents "the concepts of life, sustainability as also route the circuit."

It may symbolize the solar race represented by the act of the current king to the god or around the sanctuary. The ritual perspective $\mathrm{Sn}$ sign was able to delineate some monuments of worship the same place where the offerings were laid or which libations are poured [13], as in: CG $20032^{(\mathrm{g})}$. There is a very rare combination of the two Wedjat-eyes with two of $\check{s} n$ sign to combine 요요 as in: CG 20649. 2- The Wedjat-eyes with $n f r$ : Doha mentioned that there are on a few stelae a group of three signs $n f r$, symbolizes the regeneration of death, also interpreted as the representation of the passage of the nightlife in the day [13]. This group may reflect - according to Jéquie [19] as "being renewed or rejuvenated". This sign (group of three signs $n f r$ ) appeared decorating top of stelae between the Wedjat-two eyes to make the combination $20079^{(\mathrm{h})}$. 3- The Wedjat-eyes with $\mathrm{n}$ : allow the deceased to see the day light [5], and the beverage offerings to him [13]. On the other hand, the presence of Wadjat-eyes on the stelae reflects a ritual because the eye as Jéquie noted, plays a role in the ceremony of opening the mouth [13].

the wDAt appeared in different forms: 1- The full form named "Wedjat"[18] as a couple form in CG $20745^{(\mathrm{e})}$. 2- The small form ¿ named "The Two Eyes" [18] as a couple form令, in CG $20612^{(\mathrm{f})}$.

This sign appeared decorating top of stelae within the Wedjat-two eyes; it denotes the "God of Millions of Years". This was the standard uniform of watermen during the Old Kingdom and so may refer to the god's watery nature; it is probably a sign of ages long ago [18]. Appearing the water sign $\mathrm{n}$ together with the Wedjat-eyes has a religious meaning. It is a reference to the legend of the Eye of the High God which was sent into the waters before the beginning of the world, but this is the prototype of the nightly journey of the sun through the waters of the Underworld [18]. Also the spirit of the eternal waters is protecting the eye on its dark and dangerous journey [18]. Two water signs were represented together with the Wedjat-eyes, each eye upon one of it forming the combination of as in: CG 20368. 4- The Wedjat-eyes with ${ }^{\prime} n h$ : In ancient times, the sign of life ${ }^{\top} n h$ is done in the following way: an almond-shaped loop, which the curve is more rounded at the top, is placed above a straight vertical rod and these two elements are separated by a horizontal crosspiece, whose total length is approximately the same as the height of the lower leg, the entire sign is substantially narrower than the top. 
In well-designed pieces, both ends of the crossbar widen slightly and a horizontal rectangular room, often striated in the direction of the height is raised at the junction of the two elements, it seems to unite as one clip, on foot, it also widens a bit at the bottom, and a straight line divides in its height in two equal parts, although that closely related, appear to be the continuation of the ends of the loop that overcomes the while [19]. This sign appeared alone between the Wedjat-two eyes on a stela to make the combination of giving the meaning of mirror, there is every reason to believe that the mirror plays a role in the rebirth of the deceased 3.3.3. Other combinations

The Wedjat-eyes represented together with the sign of water and combined with other signs, as follows: 1- With wsh: The wsh represented between two eyes and two water signs $\mathrm{n}$, as in: CG $20677^{(\mathrm{j})}$ as 2- With 'nh: The 'nh represented between two combinations from Wedjat-eye upon the water sign $\mathrm{n}$, as

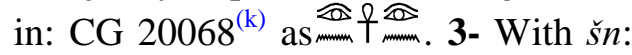

\section{Offerings}

Offerings were represented decorating top of Middle Kingdom stelae, may be as a result for the ancient Egyptian religious thoughts, as in: $\mathrm{CG}$
[13], as in: CG 20191. 5- The Wedjateyes with Jackel: The jackel sign appeared decorating top of stelae together with the Wedjat-two eyes to make the combination of 语象昰 as in: CG $20100^{(i)}$. Rarely one jackel (most probably representing Wepwawt) between two eyes as in CG 20746 as 牙负. 6- The Wedjat-eyes with other signs: A vase sign (mrht) was represented between two Wedjat-eyes making the combination of in: CG 20281. Two mrht vases were represented between two Wedjat-eyes making the combination of as in: CG 20284.

The $\check{s} n$ represented between two combinations from Wedjat-eye upon the water sign $n$, as in: CG $20622^{(1)}$ as . More than three different symbols, as: Two Wedjat-eyes, two jackels, $\check{s} n$ sign and the group of three water signs making a combination of 를 $\stackrel{0}{=}$, as in: CG 20459

20339, and a very rare decoration as two oxen with one slaughter with each of them, may be to use the ox parts as offerings, as in: CG 20572.

\section{Conclusion}

As mentioned above in this paper I was trying to through light on the decoration symbols that appeared decorating top of stelae of Middle Kingdom in Cairo Museum and the differences between these symbols and its combinations. As a result, one may find the followings: * It is clear now that the Winged sun-disk was used to decorate top of stelae of Middle kingdom but it was very rare in use. * Deities appeared also upon top of stelae. However, deities never appeared alone. They always represented together with the God Wepwawt. * The Jackel appeared representing top of stelae forming both gods; Wepwawt and Anubis, in few examples. * The most common symbol was the Wedjat-eyes in its two forms (full form, small form), which appeared alone or combined with other symbols like šn, $n f r$, ' $n h$. * The combination of Wedjat-eyes and šn symbols was the most common decoration upon top of stelae. * The sign of water within the vase combined also with the Wedjat-eyes to give the meaning of the purifying.

\section{Endnotes}

(a) See also CG 20044, CG 20188, CG

(b) See also CG 20027 20538, CG 20539, CG 20691, CG

(c) See also CG 20192 and CG 20434 20702 
(d) See also CG 20144, CG 20282, CG 20392 and CG 20748

(e) See also CG 20034, CG 20035, CG 20055, CG 20058, CG 20059, CG 20078, CG 20082, CG 20142, CG 20338, CG 20526, CG 20536, CG 20606, CG 20687, CG 20706 and CG 20730

(f) See also CG 20257, CG 20680, CG 20701, CG 20709

(g) See also CG 20136, CG 20148, CG 20186, CG 20240, CG 20273, CG

\section{References}

[1] Reisner, G., (1932). The position of early grave stelae, Vol. II, Studies presented to F. LL Griffith, Egypt Exploration Society-Humphrey Milford, London.

[2] Müller, H., (1933). Die totendenksteine des mittleren reiches, MDAIK, Vol. 4, pp: 165-206

[3] Junker H., (1934). Gîza: Grabungen auf dem Friedhof des alten reiches bei den pyramiden von Gîza. Band II. die mastabas der beginnenden V. dynastie auf dem westfriedhof, Hölder, Wien und Leipzig, , Germany

[4] Zayed, A., (1964). A free standing stela of the XIX dynasty, Rde, Vol. 16, pp: 193-208

[5] El-Sayed, F., (2005), Lawhat Alafrad fi nehayet Al-osra Al-thamnet asher mn ahd Tout Ankh Amoun hata ahed Hour Moheb, PhD, Egyptology dept. Faculty of Arts, South valley Univ., Sohag Egypt

[6] Lesko, L., (2002). A dictionary of late Egyptian, $2^{\text {nd }}$ ed., $2 \mathrm{Vol}_{\mathrm{s}}$, B.C. Scribe Publications, Berkeley, USA

[7] Hannig, R., (2006). Grosses handwörterbuch Ägyptisch-Deutsch, Philipp von Zabern, Mainz, Germany

[8] Erman, A., \& Grapow, H., (1925). Das wörterbuch der ägyptischen sprache $7 \mathrm{Vol}_{\mathrm{s}}$., Leipzig, Germany

[9] Faulkner, R., (1962). A concise dictionary of middle Egyptian, Griffith Institute, Oxford

[10] Gardiner, A., (1973). Egyptian grammar-being an introduction to
20335, CG 20383, CG 20415, CG 20445, CG 20449, CG 20537, CG 20556, CG 20593, CG 20598, CG 20613, CG 20614, CG 20623, CG 20656, CG 20686, CG 20694 and CG 20718

(h) See also CG 20659 and CG 20754

(i) See also CG 20101, CG 20155, and CG 20160

(j) See also CG 20145 and CG 20608

(k) See also CG 20277

(l) See also CG 20311

the story of Hieroglyphs, $3^{\text {rd }}$ ed. Oxford University press, London

[11] Wendt, H., (1969). Langesnscheidts der neugriechischen und Deutschen sprache, Erster Teil, NeugriechischDeutsch, Langesnscheidt, Berlin

[12] Alam, M., (2008). Kors El-shams (Al-Moganah) zo el-genah alwahed wa ain al-wogadat ala kemam al-lawhat, Alam Al-fraena, part 2, Egypt.

[13] Mustafa, D., (1993). Ä propos d'une particularité dans la décoration des tympans des stèles cintrées du nouvel empire, GM, Vol. 133, pp: 85-96

[14] Hölzl, R., (1990). Die Giebelfelddekoration von stelen des mittleren reiches, Veröffentlichungen der Institute für Afrikanistik und Ägyptologie der Universität Wien, Wien

[15] Werbrouck, M., (1941). A propos du disc ailé, $C d E$, Vol. 32, pp: 165-171

[16] Malaise, M., (1981). Inventaire des stèles égyptiennes du moyen empire porteuses de representations divines, SAK, Vol. 9, pp: 259-283

[17] Armour, R., (2001). Gods and myths of ancient Egypt, $2^{\text {nd }}$ ed., The American University in Cairo, Egypt

[18] Clark, R., (1959). Myth and symbol in ancient Egypt, Thames and Hudson, London

[19] Jéquie, G., (1946). Considérations sur les religions égyptiennes, La Baconnière, Neuchatel, Switzerland. 